ISSN : 2722-9289

http://ejournal.poltekkes-smg.ac.id/ojs/index.php/J-SiKep

\title{
Pengobatan Kanker dengan Metode Spiritual Religion Zikir Technique (SRZT)
}

\author{
Latifatul Istianah ${ }^{1}$, Indah Retno Wati ${ }^{2}$ * \\ 1,2 Fisika, Fakultas Sains \& Teknologi, Universitas Islam Negeri Walisongo Semarang, Indonesia
}

*Corresponding author : Indah Retnowati

Email: indahretnowati42@gmail.com

Received: 21 June 2020; Revised:29 Juni 2020; Accepted: 1 July 2020

\begin{abstract}
Carsinoma mammae atau kanker payudara merupakan tumor ganas pada payudara yang menginvasi daerah sekitar payudara dan menyebar keseluruh tubuh (American Cancer Society, 2014). Kanker payudara secara global menyebabkan angka kematian tertinggi untuk wanita dan epidemiologinya menyebar merata tanpa terkendali, prevelensi angka kejadian kanker payudara cukup tinggi mulai dari luar negeri sampai dalam negeri. Metode spiritual seperti dzikir dapat mengurangi tingkat kecemasan dan stres yang di alami pasien kanker.
\end{abstract}

Keyword : Kanker, Spiritual, Dzikir

\section{Introduction \\ (Pendahuluan)}

Menua adalah suatu proses menghilangnya secara perlahan lahan kemampuan jaringan untuk memperbaiki diri dan mempertahankan struktur dan fungsi normalnya sehingga tidak dapat bertahan terhadap jejas (termasuk infeksi) dan memperbaiki kerusakan yang terjadi. ${ }^{4}$ Memasuki masa tua berarti mengalami kemunduran baik fisik maupun psikis. Pada lanjut usia, gejala dari stres ini akan lebih kelihatan karena lanjut usia lebih rentan terhadap stress. ${ }^{7}$

Penyakit kanker merupakan penyakit dengan jumlah kematian tertinggi kedua setelah penyakit jantung di dunia. Kanker adalah penyakit yang tidak menular yang ditandai dengan pertumbuhan sel tidak normal/terus-menerus dan tidak terkendali yang dapat merusak jaringan sekitarnya serta dapat menjalar ke tempat yang jauh dari asalnya yang disebut metastasis. Sel kanker bersifat ganas dan dapat berasal atau tumbuh dari setiap jenis sel di tubuh manusia. ${ }^{6}$

Penyakit kanker merupakan salah satu penyebab kematian utama di dunia setelah kardiovaskular. Kanker menjadi penyebab kematian 8,2 juta jiwa di dunia pada tahun 2012 (Kemenkes RI, 2015). Menurut WHO (Word Health Organization) lebih dari $70 \%$ kematian yang terjadi di negara miskin dan berkembang disebabkan oleh kanker. $^{3}$ Kanker dengan persentase kasus baru tertinggi (setelah dikontrol dengan umur) terdapat pada kanker payudara yaitu sebesar 43,3\%. Kanker payudara ini merupakan penyebab kematian tertinggi akibat kanker. Pada perempuan kanker payudara menyebabkan kematian sebesar $12,9 \%$ (Kemenkes RI, 2015).

\section{Methods (Metode Penelitian)}

Jenis penelitian yang digunakan dalam penelitian adalah jenis deskriptif kualitatif. Penelitian kualitatif didasarkan pada data deskriptif. ${ }^{1}$ Berdasarkan judul yang diangkat, penelitian ini didasarkan pada pendekatan psikologis penderita kanker yang diharapkan mampu memberi pemahaman yang mendalam dan komprehensif.

\section{Results and Discussion (Hasil dan Pembahasan)}

Tujuan dari penelitian adalah untuk mengetahui seberapa efektif ketenangan hati untuk pasien kanker dalam menghadapi penyakitnya. Prof. Dr. M. Amin Syukur, dalam bukunya "Zikir Menyembuhkan Kankerku" mengatakan bahwa pada kenyataannya penyakit itu ada dua macam, yaitu fisik dan psikis. Keduanya bersumber dari pikiran atau perasaan 
dan dari perut. Hal ini sesuai pernyataan Al-Harits bin Kildah, seorang tabib Arab yang mengatakan, "Perut adalah sumber penyakit dan diet adalah obat segala penyakit". Baik fisik maupun psikis keduanya saling mempengaruhi. Sakit fisik bisa berpengaruh kepada sakit psikis, dan sebaliknya sakit psikis menyebabkan sakit fisik. Dengan demikian pengobatan penyakit juga dilakukan dengan dua cara; secara medis dengan obat dan konsultasi dokter sebagai ikhtiyar zhahir atau fisik, dan secara metafisik melalui dzikir, doa dan ibadah. Penggabungan antara medis dan dzikir, dalam istilah Prof. Dr. M. Amin Syukur disebut pengobatan min-plus; sikap aktif (berobat) dan sekaligus pasif (sikap pasrah).

Bagi sebagian orang terapi metafisik berupa dzikir, doa dan ibadah sering dianggap tidak rasional. Namun dalam kenyataannya jalan ini justru paling ampuh dalam bidang pengobatan. Jika lebih jauh menelusuri teks-teks agama baik itu alQuran maupun sunnah nabi, maka akan kita jumpai banyak cara-cara pengobatan dan terapi secara metafisik melalui dzikir, doa dan ibadah. Bahkan dalam pengobatan modern dan canggih cara ini juga ditempuh.

Berdasarkan hipotesis, bahwa ketenangan jiwa yang dihasilkan dengan dzikir berdampak positif terhadap sistem kekebalan tubuh (antibodi). Dzikir akan memberikan efek positif terhadap pemikiran penderita kanker. Para penderita kanker akan merasa tenang dan bisa menghadapi masalah dengan pikiran terbuka. Sehingga penderita akan menganggap penyakit yang dideritanya merupakan ujian yang diberikan Tuhan. Berbeda dengan penderita yang memiliki pikiran negatif terhadap penyakitnya. Pasien lebih mudah stress dan akan memperburuk penyakitnya. Pasien dengan tingkat ketenangan hati yang buruk akan cenderung berpikir bahwa penyakit itu datang akibat hukuman dari Tuhan.

Hasil penelitian menyebutkan semakin tenang hati para penderita maka semakin memperbesar angka kualitas hidup. Relevansi ketenangan hati dengan dzikir dengan penyembuhan kanker sangat positif. Penyembuhan kanker akan semakin mudah dengan adanya kualitas hidup yang baik

\section{Conclusion \\ (Simpulan)}

Berdasarkan penelitian yang dilakukan secara deskriptif, dapat disimpulkan adaya hubungan positif antara ketenangan hati metode dzikir dengan proses penyembuhan kanker. Bentuk penerimaan terhadap permasalahan seperti penyakit yang dianggap sebagai teguran atau cobaan, penerimaan ini dapat membawa ke dalam kehidupan yang lebih baik dan memunculkan ketenangan. Ketenangan hati menciptakan kualitas hidup yang baik sehingga membuat penyembuhan kanker berjalan dengan mudah

\section{References (Daftar Pustaka)}

1. Arikunto. 2010. Prosedur Penelitian; Suatu Pendekatan Praktik. Jakrta; Rineka Cipta

2. Hemandia Distuanarista . 2018. Pengalaman Spiritual Survivor Cervical Cancer; Studi Fenomenologi. Jurnal Keperawatan Pemikiran Ilmiah No. 4 Vol 5

3. Ilham, A. 2008. Buku Ajar Fundamental Keperawatan Konsep Proses dan Praktik. Edisi 4 Vol 2, Jakarta

4. Nugroho, W. 2006. Keperawatan Gerontik dan Geriatrik. Jakarta ; EGC

5. Rusdi, A. 2016. Efektifitas Shalat Taubah Dalam Meningkatkan Ketenangan Hati. Jurnal Psikologi Islami Vol. 2 No. 2

6. Suci Sutioningsih, dkk. 2019. Pengaruh Terapi Meditasi Dzikir Terhadap Tingkat Stres Manusia. Jurnal Keperawatan Profesional Vol. 7 No. 1

7. Zahra Devina Nurmahani. 2017. Proses Koping Religius Pada Wanita Dengan Kanker Payudara. Psikologika Vol. 22 No. 1 